\title{
PENDIDIKAN KARAKTER DALAM PERSPEKTIF TOKOH MUHAMADIYAH
}

\author{
Dyah Kumalasar \\ Prodi Pendidikan Sejarah, Fakultas Ilmu Sosial, UNY \\ dyah_kumalasari@uny.ac.id
}

Abstract: $\quad$ Muhammadiyah was founded at the time of the discriminatory education of the colonial government and the condition of Islamic education which is apprehensive. These conditions encourage KH. Ahmad Dahlan to organize a Muhammadiyah school, which combines general knowledge with religious teaching. It aims to give a balance between intellectual intelligence and spiritual intelligence in students. Character education KH. Ahmad Dahlan is based on the teachings of Islam, namely faith, science, and charity. In principle, religion is not just as knowledge alone, but must come to the practice. KH. Ahmad Dahlan rejected the Dutch colonial government's educational system at the time, which was discriminatory and very intellectual. In addition, KH. Ahmad Dahlan considers the importance of the implementation of comprehensive education, which is implemented in a cottage system, and is managed with the principle of kinship. Through the cottage system, with the togetherness of teachers and students every day, indirectly children not only learn from textbooks, but also through life they experience everyday. Character-based religious education in moral education according to KH. Ahmad Dahlan in accordance with the characteristics of Indonesian society based on religion and culture, if applied at this time also in harmony with the master character education design developed by the government.

Abstrak: $\quad$ Muhammadiyah didirikan pada saat kondisi pendidikan pemerintah kolonial yang diskriminatif dan kondisi pendidikan Islam yang memprihatinkan. Kondisi tersebut mendorong KH. Ahmad Dahlan untuk menyelenggarakan sekolah Muhammadiyah, yang memadukan pengetahuan umum dengan pengajaran agama. Hal ini bertujuan untuk memberi keseimbangan antara kecerdasan intelektual dengan kecerdasan spiritual pada siswa. Pendidikan karakter KH. Ahmad Dahlan didasarkan pada ajaran Islam, yaitu iman, ilmu, dan amal. Pada prinsipnya, agama bukan sekedar sebagai pengetahuan saja, tetapi harus sampai pada amalan. KH. Ahmad Dahlan menolak sistem pendidikan pemerintah kolonial Belanda saat itu, yang diskriminatif dan sangat intelektualis. Selain itu, KH. Ahmad Dahlan menganggap penting dilaksanakannya pendidikan yang bersifat menyeluruh, yang dilaksanakan dalam sistem pondok, dan dikelola dengan prinsip kekeluargaan. Melalui sistem pondok, dengan kebersamaan guru dan murid setiap harinya, secara tidak langsung anak tidak hanya belajar dari buku-buku pelajaran, tetapi juga melalui kehidupan yang mereka alami sehari-hari. Pendidikan karakter berbasis agama dalam pendidikan akhlak menurut KH. Ahmad Dahlan sesuai dengan karakteristik masyarakat Indonesia yang berbasis agama dan budaya, jika diterapkan saat ini selaras pula dengan desain induk pendidikan karakter yang dikembangkan oleh pemerintah.

Kata kunci: Pendidikan karakter, perspektif tokoh muhamadiyah

\section{PENDAHULUAN}

Perjalanan sejarah pendidikan bangsa Indonesia pernah mengalami masa-masa sulit, terutama pada masa penjajahan Belanda. K.H. Ahmad Dahlan adalah salah satu tokoh pendidikan yang turut memperjuangkan nasib bangsa Indonesia dalam bidang pendidikannya. Organisasi Muhammadiyah yang didirikannya menjadi salah satu gerakan pendidikan dari kelompok agama (Islam). Arti penting berdirinya Muhammadiyah saat itu menurut Kuntoro (2006:136) adalah pertama, pergulatan pendidikan dalam masa pergerakan kebangsaan menjadi memiliki basis yang luas bagi masyarakat pribumi; kedua, semangat dan nilainilai keagamaan (Islam) ikut mewarnai dan menjadi basis pergerakan kebangsaan. Muhammadiyah sebagai organisasi keagamaan mengarahkan kegiatannya pada pemurnian keyakinan dan pelaksanaan ajaran Islam di kalangan umat yang saat itu mengalami penyimpangan, kejenuhan, kemandegan, serta kemerosotan.

Pendidikan Muhammadiyah yang didirikan K.H. Ahmad Dahlan saat itu memelopori pendidikan yang menyatukan pengetahuan agama dengan pengetahuan umum sekaligus. Dengan demikian dua sisi kebutuhan dasar hidup manusia, kebutuhan material dan spiritual dapat dikembangkan secara harmonis. Di sekolah Muhammadiyah diajarkan pula Bahasa Arab sebagai mata pelajaran sehingga pemahaman mengenai Qur'an dan Hadist dapat dilakukan secara bebas oleh siswa sendiri. Anak-anak dengan demikian memperolah kebebasan berfikir dalam memahami agama (Nakamura dalam Sodiq A. Kuntoro, 2006:139). Kebebasan berfikir ini yang diharapkan sebagai proses yang membebaskan anak, sehingga tidak merasa terkekang dan merasa senang belajar agama. 


\section{PEMBAHASAN}

\section{Pendidikan untuk memperbaiki akhlak dan perilaku}

Aktivitas pendidikan yang dilakukan oleh K.H. Ahmad Dahlan berangkat dari keprihatinan beliau atas kondisi masyarakat saat itu. Keprihatinan di bidang pendidikan yang mendorong K.H. Ahmad Dahlan untuk segera melakukan perubahan dalam bidang pendidikan. Kondisi masyarakat pribumi, yang sebagian besar masih dalam kemunduran, baik dari sisi intelektual maupun keagamaan, mendorongnya mendirikan Muhammadiyah sebagai basis perjuangannya dalam bidang pendidikan dan sosial kemasyarakatan.

Pendidikan, diyakini oleh K.H. Ahmad Dahlan sebagai salah satu cara efektif untuk memperbaiki akhlak dan perilaku setiap manusia, bahkan manusia yang paling jahat sekalipun, dapat diperbaiki dengan cara memberikannya pendidikan agama, serta pendidikan tentang perilaku yang baik. Salah satu tulisan beliau yang dimuat dalam Soeara Moehammadijah no.2 (1921:11), menyiratkan tentang ide diadakannya pendidikan di dalam tembok penjara. Penjara dalam pandangannya adalah tempat belajar bagi para nara pidana agar menjadi lebih baik perilakunya. Menurutnya penjara seharusnya dibuat tidak ubahnya seperti sebuah sekolah, tempat mendidik jiwa-jiwa yang tidak baik agar menjadi lebih baik perilaku dan akhlaknya ketika dia sudah keluar dan terjun kembali ke masyarakat.

Dalam memperjuangkan cita-citanya, K.H. Ahmad Dahlan tidak pernah bersikap agresif, melainkan dengan menunjukkan sikap sebagai seorang pendidik yang bijaksana (Salam, 1960:23). Pendekatan pendidikan K.H. Ahmad Dahlan cenderung bersifat dialogis dan mengajukan pertanyaan untuk merangsang berpikir dengan cara baru. Namun sayangnya, K.H. Ahmad Dahlan jarang menuangkan buah pikirnya dalam bentuk tulisan, sehingga tidak banyak buku atau karya yang beliau tinggalkan. Beberapa tulisan yang berhasil dihimpun sebagai sumber dalam penelitian ini, merupakan buah karyanya dalam beberapa kali terbitan Suara Muhammadiyah, dan catatan pidatonya dalam pembukaan Muktamar Muhammadiyah.

Pendidikan Muhammadiyah yang mencerminkan ide atau pemikiran pendidikan K.H. Ahmad Dahlan bertujuan membentuk manusia muslim yang berakhlak mulia, cakap, percaya pada diri sendiri, dan berguna bagi masyarakat. Dihadapkan pada kondisi pendidikan pada masa kolonial Belanda yang bersifat dualistis, yaitu pendidikan di sekolah Belanda yang sekular dan pendidikan pesantren yang hanya mengajarkan pengetahuan agama saja, K.H. Ahmad Dahlan secara sederhana merumuskan tujuan pendidikan tersebut berdasarkan konsep Kyai intelek dan intelek kyai. Cita-cita tersebut mengandung makna terciptanya seorang muslim yang memiliki keteguhan iman dan ilmu yang luas. Kepada beberapa muridnya beliau menegaskan tujuan tersebut dengan kata-kata, "dadiyo kyai sing kemajuan, lan aja keselkesel anggonmu nyambut gawe kanggo Muhammadiyah", yang memiliki makna, jadilah ulama yang berpikiran maju, dan jangan berhenti bekerja untuk kepentingan Muhammadiyah. Bahkan dalam pesan terakhirnya sebelum meninggal, beliau juga menyampaikan "hidup-hidupilah Muhammadiyah, jangan mencari penghidupan dari Muhammadiyah", mengandung makna bahwa setiap aktivis Muhammadiyah harus selalu aktif, mandiri, rela berkorban, dan berjuang untuk Muhammadiyah, bukan sebaliknya, mencari penghidupan dari Muhammadiyah (Mohammad Djazman, 1990:189). Konsep kyai intelek dan intelek kyai juga mengisyaratkan bahwa pemahaman ilmu agama dan ilmu pengetahuan umum tidak boleh dipisahkan, sehingga menghasilkan kyai yang menguasai ilmu pengetahuan atau ilmuan yang menguasai agama.

Dalam rangka mengintegrasikan kedua sistem pendidikan tersebut (agama dan pengetahuan umum), K.H. Ahmad Dahlan melakukan dua tindakan sekaligus, yaitu mengajarkan agama di sekolah-sekolah pemerintah kolonial Belanda yang sekular, dan mendirikan sekolah sendiri yang mengajarkan agama dan pengetahuan umum bersama-sama.

Pendidikan yang diselenggarakan oleh K.H. Ahmad Dahlan tidak hanya bertujuan untuk mencerdaskan umat muslim secara intelektual saja, melainkan juga berupaya untuk mengembangkan kepribadiannya. Seorang muslim yang maju secara intelektual, sekaligus memahami dan memegang teguh ajaran agamanya, serta mengamalkan segala perintah agama merupakan tujuan akhir dari pendidikan yang diusahakannya. Hasil akhir yang didambakannya dari pendidikan tadi adalah terbentuknya masyarakat yang sejahtera, damai, serta terbebas dari segala kungkungan, termasuk kungkungan kolonialisme Barat.

K.H. Ahmad Dahlan telah menggagas sejak lama bahwa tujuan pendidikan yang utama itu adalah pengembangan akhlak, bukan sekedar pengumpulan pengetahuan atau ketrampilan seperti yang dilakukan dalam pendidikan yang diselenggarakan oleh pemerintah kolonial Belanda. Pendidikan akhlak dalam pandangan K.H. Ahmad Dahlan dilakukan dengan proses dialogis dalam metode yang diterapkannya dalam perkumpulan Fathul Asrar Miftahus Sa'adah, yang berorientasi pada melakukan dialog untuk mencari solusi permasalahan yang dihadapi para generasi muda, serta menekankan pada prinsip bahwa beragama adalah beramal. Mengamalkan agama sebagai upaya memperbaiki akhlak merupakan fondasi utama pendidikan karakter K.H. Ahmad Dahlan.

\section{Memadukan pengetahuan umum dan pendidikan agama}

Pendidikan mempunyai makna yang penting dalam pandangan K.H. Ahmad Dahlan. Muhammadiyah yang didirikannya pada tahun 1912 menjadi bagian dari daya kreatif umat Islam Indonesia. Muhammadiyah lahir sebagai alternatif berbagai persoalan yang dihadapi umat Islam Indonesia pada akhir abad ke-19 dan awal abad ke-20. Menurut Mulkhan (1990:1), Muhammadiyah juga merupakan konsekuensi logis munculnya pertanyaan sederhana seorang muslim kepada diri dan masyarakatnya tentang bagaimana memahami dan mengamalkan kebenaran Islam yang telah diimani sehingga pesan global Islam yaitu rahmatan lil aalamien atau "kesejahteraan bagi seluruh kehidupan" dapat mewujud dalam kehidupan obyektif umat Islam. Jika ditilik kembali, sejarah perkembangan Muhammadiyah adalah dinamika dan

HISTORIA: Jurnal Pendidik dan Peneliti Sejarah, p-issn:2620-4789 | e-issn:2615-7993 
mekanisme hubungan daya kreatif intelek manusia muslim dan berbagai persoalan hidupnya dengan norma ajaran Islam.

Kegiatan pendidikan K.H. Ahmad Dahlan sudah dimulai sebelum didirikannya organisasi Muhammadiyah. Pada tahun 1911, K.H. Ahmad Dahlan telah mendirikan sebuah sekolah agama dengan nama Sekolah Muhammadiyah (Hadikusuma, 1973:64). Lebih lanjut dijelaskan bahwa perguruan tersebut tidak diselenggarakan di surau atau langgar, seperti biasanya sekolah Islam yang ada pada saat itu, tetapi bertempat di dalam sebuah gedung, dengan menggunakan meja dan papan tulis.

Pelajaran yang disampaikan di Sekolah Muhammadiyah saat itu selain pelajaran agama, juga penggunaan huruf latin dan ilmu-ilmu lain seperti berhitung, ilmu bumi, ilmu tubuh manusia, dan sebagainya, sebagaimana yang diajarkan di sekolah-sekolah pemerintah kolonial Belanda. Muridnya awalnya hanya terdiri dari beberapa belas orang anak dan pemuda di kampungnya yang dipimpinnya dengan teliti dan bersungguh-sungguh (Hadikusuma, 1973:64). Beberapa muridnya adalah Kyai Suja' dan K.R.H. Hadjid, yang kemudian banyak menuliskan tentang kehidupan dan kegiatan pengajaran yang dilakukan oleh K.H. Ahmad Dahlan.

Kegiatan pendidikan selanjutnya dikelola secara lebih baik dalam organisasi Muhammadiyah yang didirikannya pada tanggal 18 Nopember 1912. K.H. Ahmad Dahlan dengan dibantu oleh pemuda-pemuda muridnya dan sahabatsahabatnya, mendirikan sebuah perkumpulan dengan nama Muhammadiyah. Tujuan dari organisasi ini adalah menghidupkan kembali ajaran Islam yang asli dan murni, serta tata kehidupan sesuai dengan ajaran Agama Islam, dengan kata lain, menerapkan ajaran Islam sebagai "way of life" dalam kehidupan individu dan masyarakat (Hadikusuma, 1973:64).

Nama Muhammadiyah dipilih, dinisbahkan kepada Nabi, yang berarti bahwa persyarikatan ini bermaksud menghidupkan kembali ajaran Islam seperti yang diajarkan dan dicontohkan oleh Rasulullah, serta mengikuti jejaknya dalam beramal serta berjuang menegakkan kalimah Allah. Pemerintah Hindia Belanda sempat menaruh curiga terhadap gerakan K.H. Ahmad Dahlan, sehingga permintaan kepada Gubernur Jenderal yang tertanggal 20 Desember 1912 untuk mengesahkan berdirinya persyarikatan Muhammadiyah. Permohonan tersebut baru dikabulkan pada 22 Agustus 1914, dengan Anggaran Dasar sebagai berikut: (1) memajukan serta menggembirakan pelajaran dan pengajaran agama Islam dalam kalangan sekutu-sekutunya; (2) memajukan serta menggembirakan hidup sepanjang kemajuan agama Islam dalam kalangan sekutu-sekutunya (Hadikoesoemo, 1973:68).

Rumusan sederhana dalam anggaran dasar tersebut mengandung arti, bahwa ketika umat Islam berada dalam kelemahan dan kemunduran akibat tidak mengerti kepada ajaran Islam yang sesungguhnya, maka Muhammadiyah mengungkap dan mengetengahkan ajaran Islam yang murni itu serta menganjurkan kepada umat Islam umumnya untuk mempelajarinya, dan kepada para alim ulama untuk mengajarkannya, dalam suasana yang maju dan menggembirakan. Ajaran Islam yang telah dipelajari, dipahami benar-benar dan diterapkan menjadi cara hidup setiap muslim secara maksimal, sesuai dengan kemauan ajaran Islam dan disesuaikan dengan kemampuan. Dengan demikian, secara tidak langsung Muhammadiyah menyatakan bahwa agama Islam bukan semata-mata agama pribadi dalam hubungannya dengan Allah, tetapi Islam adalah "a way of human life in all aspects”, (Hadikoesoemo, 1973:68), atau sistem kehidupan manusia dalam segala seginya, tidak hanya mengatur hubungan manusia dengan Tuhan tapi juga antara manusia dengan manusia yang lain, atau dapat dikatakan agama Islam adalah agama sosial.

Pertimbangan K.H. Ahmad Dahlan saat itu, bahwa Islam perlu diajarkan kembali kepada rakyat menurut isinya yang asli, sesuai dengan al Quran dan Hadits, sedang ajaran tambahan yang tidak berasal dari sumbernya perlu dikikis habis. Usaha ini dilakukannya oleh K.H. Ahmad Dahlan melalui Muhammadiyah dengan membuka sekolah dan madrasah, pengajaran dan tabligh serta ceramah umum. Mubaligh-mubaligh Muhammadiyah keluar masuk kampung dan dusun untuk memberikan pengajian tentang agama Islam dan membimbing memahami agama dengan menggunakan akal pikiran yang sehat. Usaha organisasi tersebut kemudian berkembang tidak hanya pada kalangan tabligh dan pengajaran, tetapi juga dalam bidang amal sosial, seperti mendirikan panti asuhan, rumah penampungan orang miskin dan balai pengobatan, serta rumah sakit. Usaha tersebut disambut baik oleh masyarakat, yang sebagian besar kondisinya miskin, akibat dari penjajahan.

K.H. Ahmad Dahlan sendiri giat mengembangkan ajaran agama Islam dan organisasi Muhammadiyah ke kampungkampung dan desa-desa. Rumah pribadinya disediakan pula untuk kegiatan pengajian kaum wanita. Pernah terjadi, K.H. Ahmad Dahlan pulang dengan membawa kurang lebih dua lusin pekerja kereta api untuk diberi makan dan minum, kemudian diajarinya sembahyang. Ia mengembangkan organisasinya ke tempat-tempat yang jauh, seperti Jakarta, Malang, Bangil, bahkan sampai Banyuwangi yang berada di ujung Pulau Jawa sebelah Timur (Hadikoesoemo, 1973:71). Berdakwah, dalam pandangan K.H. Ahmad Dahlan adalah tidak hanya dengan memberikan ceramah saja, akan tetapi yang lebih penting justru melakukan sesuatu. Memberikan contoh sebelum mengajarkannya kepada para santri merupakan konsep penting yang selalu ditunjukkan oleh beliau.

Seluruh usaha pembangunan yang dilakukan oleh K.H. Ahmad Dahlan melalui organisasi Muhammadiyah sejak awal bertujuan untuk mencerdaskan bangsa Indonesia terutama umat Islamnya, agar mampu berpikir menggunakan rasio yang sehat, meninggalkan kebekuan akal serta taklid buta yang amat merugikan perkembangan bangsa. Selain itu, yang paling penting adalah melandasi perkembangan dan kemajuan itu dengan dasar ajaran agama serta budi pekerti yang mulia (Hadikoesoemo, 1973:78).

Guna melengkapi upaya pembangunan umat, maka pada tahun 1927 dibentuk suatu bagian atau majelis dalam tubuh Muhammadiyah, yang disebut sebagai Majelis Tarjih. Majelis ini anggotanya terdiri dari para alim ulama guna menggariskan tuntunan dan hukum-hukum keagamaan dengan bersumber 
pada al Quran dan Sunnah, meskipun pendapat ulama madzhab dan para ulama juga tidak diabaikan.

Tarjih berarti mengambil hukum atau menuruti suatu paham dengan meneliti serta memilih yang lebih kuat alasannya, baik alasan berdasarkan al Quran dan Sunnah maupun berdasarkan ratio dan kebijaksanaan. Majelis ini kemudian dibentuk di daerah-daerah sampai ke cabang, dan secara rutin mengadakan pula Muktamar atau Kongres Tarjih yang utusannya berdatangan dari seluruh Indonesia serta mengundang pula alim ulama dari luar organisasi Muhammadiyah.

Setiap putusan yang diambil Muhammadiyah mengutamakan kebebasan berpikir, selama tidak menyimpang dari ketentuan firman Allah dan Sunnah Rasul. Dengan demikian orang Islam akan mampu memahami ajaran agama dengan sebaik-baiknya, juga akan mampu memahami ajaran agama dengan sebaik-baiknya, juga akan mampu membuka jalan baru bagi kemajuan umat Islam itu sendiri dalam segi ilmu pengetahuan dan peradaban, juga dalam segi ilmu pengetahuan dan peradaban, serta segi-segi yang melengkapi hajat hidup individu dan masyarakat. Misalnya, perintah Allah untuk menghadap ke Baitullah ketika orang sedang sembahyang. Perintah ini mendorong umat Islam untuk mempelajari ilmu bumi guna menentukan arah Baitullah yang terletak di Mekah itu dari berbagai tempat di Indonesia. Umpamanya dari Ambon menghadap ke Barat condong ke utara 21 derajat, dari Merauke serong 20 derajat dan dari Yogyakarta serong 24 derajat.

Sifat organisasi Aisyiyah adalah pembinaan dan pemeliharaan sesuai dengan ajaran Islam bahwa setiap berkewajiban mendidik dan memelihara agama dan akhlak seluruh keluarganya, terutama kaum wanitanya, dan yang menegaskan hak-hak wanita beserta kewajibannya yang terpisah dari kaum pria. Artinya, wanita sendirilah yang nantinya mempertanggungjawabkan hidupnya kepada Allah, tidak membonceng suaminya. Demikian pula, kaum wanita mempunyai hak untuk memperoleh kemajuan dan memajukan dirinya, dengan cara-cara yang baik serta dengan mengatur organisasi. Dapat dikatakan bahwa berdirinya Aisyiyah menjadi pelopor kebangkitan wanita Islam.

K.H. Ahmad Dahlan juga mendorong beberapa orang sahabatnya agar mereka menyekolahkan anak puterinya ke sekolah pemerintah, dan yang lain ke sekolah agama agar dapat dididik menjadi wanita yang alim. Pada tahap pertama, tiga orang anak perempuan masuk ke sekolah H.I.S. yaitu Siti Walidah, Siti Dawimah, dan Siti Bariyah. Gadis-gadis yang dididik berikutnya adalah Siti Oemniyah dan Siti Munjiyah. Angkatan selanjutnya adalah Siti Badilah, Siti Dauhah, Siti Zainab Damiri, Siti Hayinah, dan Siti Aisyah puteri dari K.H. Ahmad Dahlan sendiri. Kader-kader puteri itulah yang kemudian membantu menyiarkan gerakan Aisyiyah sehingga merata di seluruh tanah air.

Melalui Aisyiyah, kaum wanita dididik menjadi alim dan terpelajar, serta mempunyai kewenangan untuk mengajar dan berpidato di hadapan kaum pria. Dilandasi oleh keputusan Musyawarah Majelis Tarjih pada Kongres Muhammadiyah ke20 di Yogyakarta tahun 1931 yang berbunyi (Hadikoesoemo,
1973:82): “...wanita mengajar laki-laki pun dibolehkan karena tidak ada larangan yang mencegah hal itu; yang sudah tentu saja disyaratkan adanya keamanan, seperti memejamkan matahati dan tidak berkhalwat (berdua-duaan)." K.H. Ahmad Dahlan telah berhasil mendobrak kebiasaan lama yang menganggap perempuan tidak memerlukan pendidikan dan kepandaian. Tidak hanya untuk memperoleh ilmu untuk dirinya sendiri, bahkan perempuan juga tidak dilarang untuk menjadi guru, mengajarkan ilmu yang dimilikinya kepada anak laki-laki maupun perempuan.

Pada tahun 1920, K.H. Ahmad Dahlan mengajak guru-guru Muhammadiyah satu organisasi kepanduan yang berdasar Islam, dengan mendirikan Kepanduan Muhammadiyah dengan nama Hizbul Wathan, disingkat H.W. Nama Hizbul Wathan disesuaikan dengan nama partai nasional Mesir Hizbul Wathan, yang didirikan oleh Mustafa Kamil tahun 1894, dan sejiwa pula dengan ucapan Hukama (Hadikoesoemo, 1973:82): "mencintai tanah air adalah sebagian dari pada iman." Menilik dari namanya, maksud K.H. Ahmad Dahlan mendirikan kepanduan itu adalah mendidik pemuda mencintai bangsa dan tanah air dengan dasar tuntunan Islam. Pakaian seragam terdiri dari celana biru tua yang berarti lautan, kemeja warna cokelat yang bermakna daratan, bertopi bambu melambangkan tanah air Indonesia yang kaya raya. Setiap pandu H.W. melilitkan setangan merah pada lehernya, tanda berani membela kebenaran dan tanah airnya. Simbol yang digunakan adalah sekuntum bunga melati, yang oleh para pahlawan kemerdekaan seperti Pangeran Diponegoro selalu dipersuntingkan apabila bertempur menghadapi musuh. Beberapa tahun kemudian setangan merah diganti dengan hijau. Pernah K.H. Fachrudin, murid dari K.H. Ahmad Dahlan berpidato di hadapan sepasukan besar pandu H.W. (Hadikoesoemo, 1973:83), "tongkat yang sekarang ini dalam genggamanmu dan bersandar di bahumu, kemudian hari akan berobah menjadi senapan dan bedil". Ternyata apa yang dikatakannya benar, pada masa Jepang, banyak anggota H.W. memasuki Heiho dan Tentara Pembela Tanah Air, antara lain: Mulyadi Joyomartono, Yunus Anis, Kasman, dan Sudirman. Bahkan Sudirman akhirnya menjadi satu-satunya Panglima Besar Tentara Republik Indonesia.

\section{Madrasah Muhammadiyah}

Selain model klasikal, pendidikan yang diselenggarakan oleh K.H.A. Dahlan menganut juga sistem pondok, yang dikenal dengan nama Madrasah Zoe’ama dan Za'imaat. Dalam dasar dan garis-garis pendidikannya, madrasah ini bertujuan untuk mendidik pemuda laki-laki maupun perempuan supaya mempunyai faham dan kecakapan sebagai pemimpin, penasehat, atau juga sebagai sumber ilmu dan laku keutamaan Islam pada umumnya dan dari usaha Muhammadiyah khususnya (Madrasah Moehammadijah, 1939:4). Pondok ini semacam boarding school yang tingkatannya lebih tinggi dari Mu'alimin dan Mu'alimat yang masih ada saat ini, atau setingkat diploma. Mereka yang lulus dari sini akan disebarkan sebagai juru dakwah di daerah. Untuk mencapai tujuan tersebut, maka yang dilakukan adalah menanamkan pengertian dan kacakapan hidup sesuai tuntunan agama Islam, serta semangat, pengertian, kecakapan, dan keringanan

HISTORIA: Jurnal Pendidik dan Peneliti Sejarah, p-issn:2620-4789 | e-issn:2615-7993 
untuk menjalankan pengajaran tentang ilmu-ilmu dan laku keutamaan dari agama Islam dan dari usaha Muhammadiyah.

Garis pendidikan madrasah Zoe'amaa dan Za'imaat mengikuti Al Quran dan Hadits, sebagai landasan dalam mengusahakan kealiman hidup dan luasnya ilmu, yang diperlukan bagi seorang pemimpin kelak. Disertai pula dengan pengertian dan kecakapan hidup yang merdeka dan suci sesuai kedudukan atau posisi murid di kelak kemudian hari. Menurut garis dasar pendidikan Muhammadiyah, segala cita-cita tersebut dapat dicapai dan diusahakan apabila murid bertempat tinggal di dalam pondok, bersamasama dengan guru-gurunya serta tempat madrasahnya (Madrasah Moehammadijah, 1939:5). Sistem pondok ini yang dikhususkan bagi murid yang dipersiapkan menjadi guru di sekolah Muhammadiyah atau menjadi da’i (penyebar agama).

Gedung madrasah dan pondok untuk murid laki-laki dan perempuan sengaja dipisahkan, demi menghormati muridmurid perempuan sesuai ajaran Islam. Adapun pengajaran dan pendidikannya, disesuaikan dengan kebutuhan masingmasing calon pemimpin baik yang laki-laki maupun perempuan. Sesuai sumber Madrasah Moehammadijah (1939:5) murid laki-laki disebut sebagai "bakal pemimpin laki" dan murid perempuan disebut sebagai "bakal pemimpin isteri".

Berdasarkan dasar dan garis-garis hidup pondok disebutkan bahwa guru dan murid dari Zoe'amaa maupun Za'imaat, masing-masing bertempat tinggal di dalam pondok. Masing-masing golongan menjadi keluarga, melangsungkan segala cara yang baik dari pondok pesantren kuno, serta tetap mengindahkan internaat (pondok model adab Barat). Keduanya dilakukan karena yang penting bermanfaat dan perlu, guna kesempurnaan pendidikan dan pengajaran, dan yang lebih penting lagi demi mengusahakan agar keyakinan (iman) dari bakal pemimpin mengakar (asli) dari tenaga dan perbuatan.

Kebersamaan hidup di dalam pondok, membuat guru mempunyai kelonggaran dalam waktu untuk memperhatikan dan menjalani kekhususan dari setiap murid-muridnya. Selain itu guru juga mempunyai banyak waktu untuk mencontohkan segala perilaku sesuai sunah yang menambah keutamaan bakal pemimpin sesuai kehendak masing-masing, seperti sholat Tahajud, berpuasa, dan lain-lain. Selanjutnya guru dan murid wajib mempergunakan kelonggaran waktu dari kebersamaan yang ada guna kesempurnaan ilmu dan laku. Hidup dalam satu pondok memungkinkan guru untuk terus memantau perkembangan murid dari waktu ke waktu dan sekaligus memberiikan contoh dan keteladanan dalam hidup keseharian.

Kewajiban lain bagi guru dan murid yang tinggal di dalam pondok adalah melakukan sholat berjamaah atau sholat bersama-sama. Di dalam pondok juga disediakan Koran dan buku-buku dalam Bahasa Arab, Indonesia, dan Jawa. Disediakan pula segala perlengkapan dan fasilitas yang mendukung proses pembelajaran.

Hidup bersama di dalam pondok memungkinkan guru maupun murid untuk memanfaatkan waktu dengan lebih leluasa. Disebutkan bahwa, apabila karena suatu hal pengajaran tidak dapat dilaksanakan pada pagi hari, maka boleh dilakukan pada sore harinya antara jam 4-6 sore, atau bahkan pada jam 8-10 malam sesuai dengan kepentingannya. Pemimpin pondok juga mempunyai kewenangan untuk menolak datangnya orang-orang dari luar kalau dipandang perlu.

Setiap aturan tata tertib keseharian di dalam pondok Za'imaat maupun Zoe'amaa diserahkan kepada masingmasing murid, dengan tujuan agar mereka memperhatikan dan terbiasa mengatur diri sendiri. Murid diberi kepercayaan untuk ikut berperan dalam membuat aturan tata tertib di dalam pondok. Murid yang melanggar aturan yang sudah disepakati bisa dikeluarkan oleh atau atas nama majelis pengajaran. Hal ini dilakukan supaya murid dapat menghargai aturan yang sudah disepakati bersama dan lebih disiplin.

Tujuan pendidikan dalam sistem pondok adalah untuk menyiapkan murid supaya memahami dan menguasai dengan baik ilmu-ilmu agama Islam serta mengamalkannya. Setelah menguasai dan mengamalkan dengan baik, mereka juga mampu mengajarkan serta memimpin pengajaran agama Islam, mengerti dan cakap menjalankan, serta memimpin usaha amal menurut agama Islam pada umumnya dan usaha Muhammadiyah pada khususnya. Bekal utama dalam pengajaran adalah ilmu-ilmu agama Islam, oleh karena itu guna dalamnya pengajaran maka bahasa Arab diutamakan.

Materi pengajaran yang diberikan di Madrasah Muhammadiyah meliputi pelajaran agama Islam dan pengetahuan umum. Disebutkan dalam Madrasah Moehammadijah (1939:6) bahwa, demi tercapainya tujuan maka amalan (practiche sociologie) dalam kehidupan seharihari dan hal ihwal tentang Muhammadiyah diajarkan secara terus menerus. Selain itu, guna penyiaran agama, maupun dalam organisasi, maka diberikan juga pelajaran seperti Bahasa Indonesia (untuk murid Jawa diberi juga Bahasa Jawa); pengetahuan umum (burgerkunde); ilmu jiwa (psychologie); dan ilmu mengajar umum (algemeene methodiek). Apabila diperlukan dan masih ada waktu, diberikan pula pelajaran Bahasa Inggris, guna melanjutkan pendidikan ke universitas di luar negeri atau di tanah sendiri, untuk pergi haji, serta untuk perluasan pengetahuan agama pada umumnya.

Supaya di kemudian hari, murid itu mampu menjadi pemimpin keislaman serta dapat mencukupi nafkahnya sendiri, diberikan pula pemahaman dan kecakapan tentang penghidupan yang suci dan merdeka. Termasuk di antaranya: (1) vak guru agama (termasuk pelajaran agama dan keamalan); (2) tani dan ternak (hanya untuk murid laki-laki); (3) dagang; (4) kerajinan (yang suci dan merdeka). Demi pendalaman pengajaran yang diberikan, maka diusahakan pula dengan pengadaan perpustakaan dan pembacaan koran; radio (dengan ditentukan apa saja yang boleh didengar, disesuaikan dengan pendidikan bakal pemimpin); pernyataan, percobaan, dan kunjungan.

Pengajaran yang diselenggarakan dalam Madrasah Muhammadiyah sangat mengedepankan pengajaran yang mendalam dan hidup.

...dengan tidak mengoerangkan penghargaan kepada kepentingan atas banjak dan loeasnja pengadjaran, perloe selaloe diperingati, bahwa jang paling perloe HISTORIA: Jurnal Pendidik dan Peneliti Sejarah, p-issn:2620-4789 | e-issn:2615-7993 
jaitoe pengadjaran jang diberikan dengan mendalam dan berdjiwa (hidoep = bezielend)...(Madrasah Moehammadijah, 1939:6).

Sistem pondok sangat memungkinkan dilaksanakannya pendidikan yang mendalam dan hidup, karena dengan kebersamaan antara guru dan murid selama 24 jam memberii kesempatan kepada guru untuk tidak hanya memberiikan teori namun sekaligus memberikan contoh dengan melaksanakannya dalam kehidupan sehari-hari. Dengan demikian pengajaran yang dilakukan menjadi lebih mendalam dan lebih hidup.

Setiap bagian ilmu yang diberikan harus pula memperhatikan hubungan dan saling keterkaitan antara ilmu yang dipelajari dengan kenyataan yang dihadapi setiap murid. Apalagi bagi bakal pemimpin, harus selalu diusahakan kesempatan dan usaha untuk meningkatkan semangat mewujudkan apa yang sudah dipelajari. Dalam sistem pendidikan Madrasah Muhammadiyah, usaha tersebut lebih didahulukan daripada memperbanyak dan memperluas pengajaran.

Posisi guru dalam sistem pondok Madrasah Muhammadiyah adalah pokok untuk berhasilnya proses pengajaran. Buku bermanfaat untuk membiasakan murid mencari ilmu sendiri, untuk mengulangi pelajaran dan menyatak bersama-sama. Saat guru berhadapan dengan murid adalah untuk berhubungan fikiran dan rasa dengan leluasa. Hubungan guru-murid tersebut sebisa mungkin tidak terganggu oleh keberadaan buku. Oleh karenanya, guru harus benar-benar paham tentang ilmu dan cara yang akan diajarkan, harus pula memahami terlebih dahulu isi buku yang hendak diajarkan.

Daftar pengajaran keseharian yang dibuat, tidak hanya berdasar pada banyak dan luasnya ilmu, tapi lebih penting lagi untuk diingat mendalamnya, dan hidupnya proses pengajaran. Ilmu agama berbeda dengan ilmu hitung atau ilmu-ilmu yang diajarkan di sekolah biasa, oleh karenanya, lama guru mengajar di dalam kelas tidak boleh kurang dari dua pengajaran masing-masing 45 menit. Bahkan jika diperlukan, waktu sore jam 4-5 dan malam jam 8-10 dipergunakan untuk mengajarkan pelajaran yang tidak bisa diajarkan pada pagi hari.

Dasar dari proses pengajaran di dalam pondok Madrasah Muhammadiyah, bahwa menurut faham agama Islam, bahwa,

...kejakinan (iman) tidak boleh tinggal kejakinan, melainkan kejakinan (iman) adalah akar (asl) dari tenaga atau perboeatan. Dari itoe bakal Pemimpin keIslaman, selama belajar haroes mendapat pimpinan siang dan malam, dengan bertempat tinggal di dlaam pondok, tempat tinggal Goeroe dan Madrasahnja (Madrasah-Moehammadijah, 1939:8).

Berlatar belakang itulah, maka diselenggarakan pula pendidikan dalam sistem pondok, di mana guru dan murid dapat berinteraksi secara maksimal, demi tercapainya cita-cita, mencetak bakal pemimpin keislaman yang saat itu dianggap mendesak untuk memperbaiki kondisi umat Islam.

Tinggal di dalam pondok bertujuan menjadikan bakal calon pemimpin tidak asing dengan dunia raja, zaman, dan masyarakatnya. Bahkan harus mengerti seluk beluknya, yang perlu untuk mempertajam, memperluas, dan memperdalam keyakinan, penglihatan (visi), dan sikap keislamannya. Untuk tujuan itulah maka madrasah yang mendidik bakal pemimpin keislaman (Zoe'amaa dan Za'imaat), baik sebagai guru maupun da'i, tidak cukup jika hanya berdiri sebagai madrasah atau sekolah biasa, melainkan harus bersifat pondok pesantren yang sempurna (yang modern). Modern di sini dalam artian, tetap melangsungkan segala kebaikan dari sifat pendidikan pondok pesantren kuno, tetapi mengindahkan pula segala adab (cultuur) dari mana saja, asalkan bermanfaat untuk pendidikan itu.

Persyaratan yang harus dipenuhi bagi calon siswa di Madrasah Zoe'amaa, antara lain: (1) beribadah, katam Al Quran, bisa menulis dengan huruf Arab; (2) setidaknya telah lulus dari Volks School, tamatan Vervolg School atau berpengetahuan lebih tinggi diutamakan; (3) usia minimal 13 tahun, dan maksimal 16 tahun; (4) telah mengetahui peraturanperaturan dari madrasah Zoe'amaa, dan menyatakan kesediaan untuk menaatinya; (5) telah memasukkan surat permintaan untuk masuk (Peratoeran Madrasah Zoe'amaa dan Za'imaat Moehammadijah Djokjakarta, 1940:13).

Pada pasal ke-2 peraturan Madrasah Zoe'amaa dan Za'imaat (1940:13), disebutkan bahwa:

1e. Anak jang berasal dari loear Djokjakarta wadjib bertempat tinggal di dalam Pondok Zoe'amaa (Za'imaat); 2e. Anak jang asal dari Djokjakarta diandjoerkan soepaja bertempat tinggal didalam pondok itoe; 3e. Tentang hal ichwal pondok Zoe'amaa dan pondok Za'imaat diadakan peratoeran meloeloe (harap diperiksa di belakang)

Berdasarkan sumber tersebut, dapat disimpulkan bahwa setiap murid dari Madrasah Zoe'amaa maupun Za'imaat disarankan untuk tinggal di dalam pondok. Jika dirunut dari sumber yang sebelumnya, maksud dari anjuran tersebut, kemungkinan besar disebabkan karena sebagian besar pendidikan, terutama yang non akademis banyak diberikan di luar jam pengajaran. Pada pasal ke-4 dari sumber yang sama, disebutkan bahwa jam pengajaran berlaku mulai jam 07.15 pagi sampai dengan jam 12.45 siang, pelajaran tambahan diberikan pada jam 4-5 sore dan jam 8-10 malam. Oleh karenanya, maka semua murid dianjurkan untuk tinggal di dalam pondok.

Tata cara berpakaian di dalam pondok ditentukan pula dalam Peratoeran Madrasah Zoe’amaa dan Za'imaat (1940:14-15), bahwa pakaian untuk murid Zoe'amaa selama waktu pelajaran harus berpakaian lengkap, sebagaimana seorang mubaligh yang tertib pada saat menjalankan tabligh. Ditanamkan pula kesadaran bahwa Allah selalu mengetahui segala pikiran, perkataan dan perbuatan mereka seharihari, agar segala tindakan keseharian selalu sejalan dengan tuntunan agama Islam. 
Ditanamkan pula bahwa semua anak yang di dalam pondok beserta dengan guru-gurunya adalah satu keluarga, yang bersama-sama mempunyai satu maksud, yaitu memperdalam ilmu-ilmu agama Islam dan meluhurkan agama Islam (Peratoeran Madrasah Zoe'amaa dan Za'imaat, 1940:17). Ada ketentuan pula, bahwa setiap anak di dalam pondok adalah merdeka, tetapi kemerdekaan itu tidak boleh mengganggu kemerdekaan orang lain, dan kemerdekaan itu tidak boleh merugikan dirinya sendiri, karena kurang pengertian atau karena hawa nafsunya.

Tujuan bersekolah di Madrasah Zoe'amaa dan Za'imaat adalah untuk mencapai martabat yang tinggi di kemudian hari, serta cakap menjadi pemimpin dan tauladan keIslaman. Oleh karena itu, maka di dalam pondok terutama, masing-masing anak wajib membiasakan segala perkataan dan perbuatannya yang baik, dan selalu mengingat tujuan mulianya. Dicontohkan seperti pada saat makan dan minum bersama, anak-anak dilarang bersendau gurau, berbicara yang tidak perlu, dan wajib berpakaian yang sopan menurut anggapan umum (Peratoeran Madrasah Zoe'amaa dan Za'imaat, 1940:14-17).

Selain peraturan-peraturan di atas, setiap anak di dalam pondok juga dibiasakan untuk mengerjakan pekerjaan rumah, seperti menyapu bilik, mencuci dan menyeterika pakaian, membersihkan sepedanya, dan sebagainya. Di luar segala kewajiban tersebut, setiap anak juga dianjurkan untuk mengikuti kegiatan bercocok tanam. Anak-anak diberi kesempatan untuk bermufakat bersama-sama guna ketertiban hidup pondok (Peratoeran Madrasah Zoe'amaa dan Za'imaat, 1940:18).

Khususnya untuk Madrasah Za'imaat, harapan-harapan dari diselenggarakannya pendidikan sistem pondok di Muhammadiyah tersebut, dicantumkan dalam Peratoeran Choesoes Boeat Madrasah dan Pondok Za'imaat (Madrasah Moehammadijah, 1939:90). Pada fatsal 1b disebutkan bahwa untuk pendidikan Bakal Pemimpin Isteri Islam (Za'imaat) tetap bersandar pada pertimbangan-pertimbangan seperti:

a. mereka yang akan menjadi guru yang pertama dan pendidik bagi anak-anaknya. Sempurnanya pendidikan anak-anak hanya akan didapat apabila golongan isteri berwawasan cukup dan berilmu, berbudi mulia, dan beramal solikh;

b. kaum isteri adalah pemimpin rumah tangga yang bertanggungjawab atas rumah tangganya sebagaimana peribahasa Arab yang berbunyi: "rumah tangga itu satu kerajaan yang pimpinannya dipegang oleh kaum perempuan";

c. kesucian dan kesempurnaan pendidikan kaum isteri menjadi tiang bagi keselamatan pergaulan hidup;

d. pergerakan kaum isteri kini, terutama pergerakan Aisyiyah, menghajatkan sekali akan pemimpinpemimpin (Za'imaat) dari golongan isteri sendiri, yaitu pemimpin isteri yang berilmu, beramal, dan berbudi baik, dengan singkat yang bersemangat, berpengertian, dan berkecakapan yang cukup untuk memegang pimpinan kaum isteri dengan sungguh dan bertindak aktif dan bijaksana.
Dengan demikian, jelaslah bahwa tujuan didirikannya Za'imaat adalah untuk mencetak calon pemimpin perempuan yang dapat berkiprah secara maksimal, minimal dalam rumah tangganya sendiri, dalam mendidik anak-anaknya kelak.

Adapun peraturan bagi calon murid di Madrasah Za'imaat adalah sebagai berikut:

a. yang diterima di kelas 1 madrasah Za'imaat adalah gadisgadis yang berumur paling sedikit 12 tahun dan paling banyak 15 tahun;

b. madrasah Za'imaat tidak menerima isteri yang bersuami atau pernah bersuami, sedang bagi murid yang kemudian bersuami tidak diperbolehkan melanjutkan pelajarannya. Ketentuan-ketentuan yang dibuat tersebut bertujuan agar para murid yang belajar di madrasah Za'imaat adalah benarbenar yang belum berkeluarga, karena jika sudah berkeluarga tentu saja akan mengganggu aktivitas rumah tangga dari keluarganya, karena harus menginap di dalam pondok.

Ketentuan-ketentuan dan peraturan bagi guru ditentukan pula dalam mengatur keseharian di dalam pondok. Para guru dilarang mengajarkan atau mendidik tentang hal yang menyebabkan murid salah i'tiqad dan segala hal yang bertentangan dengan keIslaman dan keMuhammadiyahan. Guru wajib menjadi contoh atau suri tauladan bagi murid. Baik di dalam maupun di luar Madrasah, guru wajib mempertahankan keluhuran agama Islam dan Persyarikatan Muhammadiyah, dan dilarang berbuat sesuatu yang melanggar, bertentangan, atau tidak sesuai dengan ajaran Islam, Muhammadiyah, dan anggapan kesopanan pada umumnya. Guru wajib pula mencatat adanya kecakapan, kemajuan, dan akhlak dari murid-muridnya, dan setiap waktu harus siap jika ada pertanyaan seputar itu dari siapapun juga (Peratoeran Madrasah Zoe'amaa dan Za'imaat, 1940:20). Dengan begitu, guru wajib memberikan perhatian penuh kepada para muridnya. Demi kedisiplinan, aturan ketat diberlakukan terhadap murid dan semua guru di dalam pondok. Selain mengajarkan tentang ilmu agama, akhlak, perilaku, kedisiplinan juga menjadi satu hal yang dianggap penting, karena dari madrasah inilah nantinya dicetak kaderkader calon pemimpin selanjutnya.

\section{Simpulan}

K.H. Ahmad Dahlan berjuang memadukan pendidikan agama sebagai bagian yang tidak terpisahkan dari pengetahuan umum di sekolah. Ide menggabungkan antara pengajaran agama dengan pengetahuan umum diwujudkannya dengan mendirikan sekolah Muhammadiyah yang mengajarkan agama dan pengetahuan umum secara bersama-sama. K.H. Ahmad Dahlan menganggap pengajaran agama di sekolah secara teratur mendesak untuk segera dilakukan, dalam rangka memberikan pendidikan moral bagi para siswa.

Pemikiran pendidikan tersebut dilatarbelakangi oleh kondisi pendidikan Barat yang diselenggarakan oleh pemerintah kolonial, yang berjalan sangat lambat dan diskriminatif, serta kondisi pendidikan Islam yang memprihatinkan. Sifat diskriminatif pendidikan pemerintah kolonial terletak pada perbedaan pelaksanaan pendidikan 
bagi pribumi dan bagi orang-orang keturunan Belanda sendiri. Politik gradualisme, sengaja dilakukan oleh Pemerintah Belanda dalam penyelenggaraan pendidikan. Penyelenggaraan pendidikan yang sengaja dibuat sangat lamban serta membiarkan penduduk Indonesia dalam kondisi pendidikannya tidak mengalami kemajuan. Pendidikan Barat hanya diperuntukkan bagi orang-orang keturunan Eropa dan beberapa orang pribumi dengan berbagai kriteria.

\section{REFERENSI}

Alfian. 2010. Politik kaum modernis, perlawanan Muhammadiyah terhadap kolonialisme Belanda. Jakarta: Al Wasath

Dahlan, A. 1985. “Tali pengikat hidup manusia”, dalam buku Perkembangan pemikiran Muhammadiyah dari masa ke masa, menyambut muktamar ke-41. Yogyakarta: PT Dua Dimensi Mulkhan,A.M. 1990. Pemikiran Kyai Haji Ahmad Dahlan dan Muhammadiyah, dalam perspektif perubahan sosial. Jakarta: Bumi Aksara

Daris Tamim. 1990. "Muhammadiyah di mata rantai perjalanan bangsa". Dalam buku Muhammadiyah, sejarah, pemikiran, dan amal usahanya. Yogyakarta: PT Tiara Wacana
Mulkhan,A.M. 2010. Pesan dan kisah Kiai Ahmad Dahlan, dalam hikmah Muhammadiyah. Yogyakarta: Suara Muhammadiyah

Mu'ti, A. 2008. Pluralisme keagamaan dalam pendidikan Muhammadiyah: studi kasus di Ende, Serui, dan Putussibau. Disertasi. Jakarta: UIN Sjarif Hidayatullah

Tafsir, A. 1987. "Konsep pendidikan formal dalam Muhammadiyah". Disertasi. Jakarta: UIN Sjarif Hidayatullah

Shihab, S. 1998. Membendung arus, respons gerakan Muhammadiyah terhadap penetrasi misi Kristen di Indonesia. Jakarta: Mizan.

Syuja, K. 2010. Islam berkemajuan, kisah perjuangan K.H. Ahmad Dahlan dan Muhammadiyah masa awal. Tangerang: Al Wasath

Zarkasyi, A.S. 2010. Membangun kepribadian dan karakter bangsa melalui pendidikan. Makalah. Disampaikan dalam seminar nasional FISE UNY 12 Mei 2010 